\title{
Determination of astilbin in dietary supplements containing Smilax glabra using high-performance liquid chromatography
}

\author{
Tran Nguyen Ha ${ }^{1}$, Hoang Thi Thuy Linh ${ }^{1}$, Vu Ngan Binh ${ }^{1}$ \\ Nguyen Thi Thanh Nhai ${ }^{2}$ Phi Van Toan ${ }^{3}$, Pham Thi Thanh $\mathrm{Ha}^{1^{*}}$ \\ ${ }^{1}$ Hanoi University of Pharmacy, Hanoi, Vietnam \\ ${ }^{2}$ Hai Duong Central College of Pharmacy, Hai Dưong, Vietnam \\ ${ }^{3}$ Hanoi University of Science and Technology, Hanoi, Vietnam
}

(Received: 03/05/2021; Accepted: 07/06/2021)

\section{Abstract}

Smilax glabra rhizoma (SGR) has been used in traditional medicine remedies for the treatment of joint pain and inflammation, and recently, has been presented in dietary supplements for supporting arthritis and gout treatment. In the $5^{\text {th }}$ Vietnamese Pharmacopoeia, astilbin was chosen as a chemical marker for the quality control of Smilax glabra as herbal medicine. A high performance liquid chromatographic (HPLC) method was developed for the qualitative and quantitative determination of astilbin in dietary supplements containing Smilax glabra. Ultrasonic extraction with $60 \%$ methanol was used for astilbin extraction from herbal products. HPLC analysis was performed with a C18 column and a mobile phase consisting of methanol and water in gradient mode, with UV detection at $291 \mathrm{~nm}$. The method was validated according to AOAC International's requirements with high specificity and precision.

Keywords: astilbin, Smilax glabra, dietary supplement, high performance liquid chromatography, HPLC.

\section{INTRODUCTION}

Smilax glabra Roxb. is a plant that grows wildly in the mountainous areas in Vietnam. For a long time, in Chinese and Vietnam Traditional Medicines, Smilax glabra rhizoma (SGR) has been used in many remedies to treat diseases of tendons, parasitic worms, ulcer, detoxification, anti-inflammatory, treatment of leptospirosis, dermatitis, syphilis, brucellosis, acute bacterial dysentery [1]. Modern medicine also shows that Smilax glabra rhizoma's root contains astilbin (AST), which plays an important role in reducing uric acid in the blood by inhibiting the activity of the enzyme xanthine oxidase and increasing the expression of uric acid secretion [2], and also has the effect of reducing the inflammatory response through inhibition of inflammatory mediators [3]. In addition to the fact that SGR presents in pharmaceuticals, it also presents in dietary supplements which are widely used without a doctor's prescription. Therefore, quantifying AST in dietary supplements to control product quality becomes necessary.

In Vietnam, there are some studies about chemical components [-], biological activity [4-5] qualitative and quantitative methods of SGR [5]. In Vietnamese Pharmacopoeia V, AST has been selected as a marker in both qualitative and quantitative criteria for SGR as a medicinal herb [7]. There are some publications of quantitative methods of AST in Smilax glabra rhizoma, which 
utilized high-performance liquid chromatography (HPLC) [4, 7]. However, there has not been any method to determine AST in supplement products from Smilax glabra rhizoma. Therefore, this study aims to develop a quantitative method to determine astilbin in dietary supplements containing SGR by HPLC.

\section{MATERIALS AND METHODS}

\subsection{Materials}

AST standard was purchased from Biopurify Phytochemicals (China) (98\%, Lot.No. PRF9022741); Smilax glabra rhizoma standard material was obtained from National Institute of Drug Quality Control (Vietnam) (SKS: CV 0116035.01); 5 samples of dietary supplements (code from $\mathrm{T} 1$ to $\mathrm{T} 5$ ) which are preparations in the form of hard capsules containing dried medicinal herbs including Nanocare, Khuong Thao Dan, Goutcare, Vien gout Tam Binh, Vuong Thao Kien Cot. Among those samples, the T1 sample was used as the matrix sample to develop the quantitative method.

\subsection{Equipment and chemicals}

An Agilent 1200 series Gradient HPLC with diode-array detection (DAD), Agilent Chemstation software (Agilent, Us) was used for the separation, qualitative and quantitative determination of AST. Methanol $(\mathrm{MeOH})$ of HPLC grade and other chemicals at analytical grade were obtained from Merck, Germany.

\subsection{Methods}

Method development: We conducted the extraction solvent selection, and other extraction parameters. Based on some references, we optimized liquid chromatography conditions such as components of mobile phases, and gradient program.

Method validation: We validated the method according to the guidelines of AOAC International Appendix K [] with some criteria of selectivity, system suitability, calibration curve, limit of detection (LOD), limit of quantification (LOQ), accuracy, and precision.

To test the applicability of the method, we have quantified AST in several commercially available dietary supplements with SGR as one of the main ingredients.

\section{RESULTS AND DISCUSSION}

\subsection{Method development for quantitation determination of astilbin in dietary supplements containing Smilax glabra rhizoma}

\subsubsection{Investigation of chromatographic conditions}

We investigated the chromatographic conditions for quantifying AST in SGR referring to Vietnamese Pharmacopoeia V, the conditions were as follow: C18 column $(250 \times 4.6 \mathrm{~mm}$ i.d.; particle size $5 \mu \mathrm{m}$ ), detection wavelength of $291 \mathrm{~nm}$, a flow rate of $1 \mathrm{~mL} / \mathrm{min}$, injection volume of $20 \mu \mathrm{L}$, a mobile phase of methanol $(\mathrm{MeOH})-1 \%$ acetic acid in water $(39: 61, \mathrm{v} / \mathrm{v})$. The results showed that the AST peak could not be separated from the product matrix. We, then, investigated two other mobile phase systems: a) $\mathrm{MeOH}-0.1 \% \mathrm{H}_{3} \mathrm{PO}_{4}$ in water; b) $\mathrm{MeOH}$ $-\mathrm{H}_{2} \mathrm{O}$ with different ratios. Consequently, the mobile phase of $\mathrm{MeOH}-\mathrm{H}_{2} \mathrm{O}(38: 62$, v/v) gave the best separation of AST peak, and high feasibility for implementation. However, the other 
compounds in the matrix had a relatively strong interaction with the column so the total analysis time was relatively long. Based on the retention time, to obtain faster elution of interferences in the matrix, the gradient program of $\mathrm{MeOH}-\mathrm{H}_{2} \mathrm{O}$ was as follows: $0-23 \min (38: 62, \mathrm{v} / \mathrm{v}) ; 23.1$ - $32 \min (85: 15, \mathrm{v} / \mathrm{v}) ; 32.1-37 \min (38: 62, \mathrm{v} / \mathrm{v})$.

\subsubsection{Investigation of extraction method}

T1 sample was firstly extracted following the method in the Vietnamese Pharmacopoeia V. An amount of sample equivalent to $0.8 \mathrm{~g}$ Smilax glabra rhizome was weighed, then reflux extraction was conducted with $100 \mathrm{~mL}$ of $60 \% \mathrm{MeOH}$.

However, the extraction of astilbin in dietary supplements is considered easier compare to the extraction from Smilax glabra rhizome herbal. Thus, T1 sample was also extracted in $60 \%$ $\mathrm{MeOH}$ with the support of ultrasonic for ten minutes (AST is soluble in this solvent).

The amount of AST in the T1 sample extracted by two methods was reported in Figure 1.
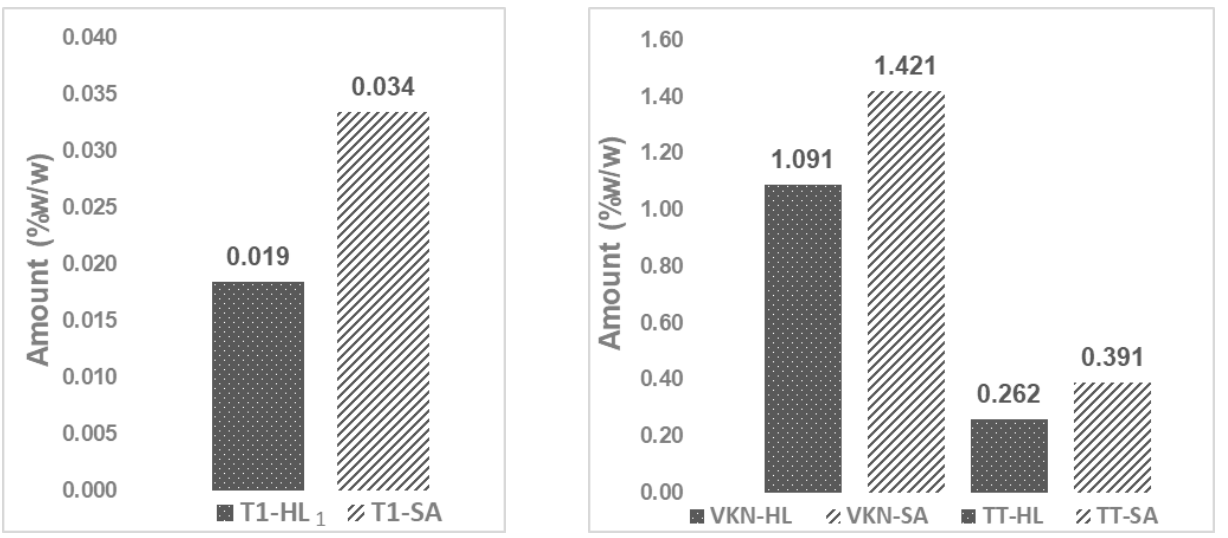

Figure 1. Amount \% of astilbin in T1 sample, SGR standard material (VKN), and commercial product (TT) extracted by reflux extraction (HL) and ultrasonic (SA)

For the same sample extracted with two methods, the amount of AST extracted by SA tended to be higher than that of HL method. The research of Qing-Feng Zhang's group (2013) showed that astilbin can be decomposed with a temperature greater than $45^{\circ} \mathrm{C}$; at the temperature of $55^{\circ} \mathrm{C}, \mathrm{t}_{1 / 2}$ was about 2.5 hours [6]. Our research group verified this result by an experiment. After 30 minutes of heating the AST standard solution to $50^{\circ} \mathrm{C}$, the concentration reduced significantly. In the HL extraction method, the temperature of methanol was about $70^{\circ} \mathrm{C}$. Thus, the reason for the low efficiency of HL extraction was thermal decomposition. Therefore, the SA extraction method was selected to extract AST from dietary supplements.

Our research group also compared the HL extraction method according to the Vietnamese Pharmacopoeia V and SA extraction method for raw material of SGR. The samples were SGR standard material (VKN sample) obtained from the National Institute of Drug Quality Control (Vietnam) and the commercial one (TT sample). The results (Figure 1) showed that the amount of AST in samples extracted by the SA method was higher than that of the HL method.

\subsubsection{Investigation of extraction time}

T1 sample was extracted by the SA method with different ultrasonic times in 5, 10, 20, 30 minutes, then analyzed by HPLC-DAD. The result of ultrasonic for ten minutes increase $7.1 \%$ compared to ultrasonic for five minutes. After ultrasonic 20 minutes, the amount of AST 
barely increased or increased insignificantly compared with the result of ultrasonic ten minutes. Ultrasonic 30 minutes showed a tendency to decrease AST. Although there was no heating process, after 20 minutes of ultrasonic, the temperature of the extraction solution started to increase, and after 30 minutes of ultrasonic, the temperature of the solution was greater than $50^{\circ} \mathrm{C}$. Thus the amount of AST decreased when increasing the ultrasonic time by thermal decomposition. In conclusion, to save time and avoid decomposition of AST, the extraction time with ultrasonic was ten minutes.

\subsubsection{Investigation of number extraction replications}

Sample $\mathrm{T} 1$ was extracted three times, the solvent volumes were 5,3 , and $2 \mathrm{~mL}$, respectively, and each time was extracted by ultrasonic for ten minutes with $60 \% \mathrm{MeOH}$. The result of HPLCDAD analysis showed that after the first extraction, most of AST was extracted, and the amount was $0.0296 \%(w / w)$. Extraction solutions of the second and the third time did not show any signal of AST in the chromatogram. Therefore, one time ultrasonic extraction for ten minutes was considered as complete AST extraction.

Finally, the sample preparation method was as follows: weighing an amount of sample equivalent to $50 \mathrm{mg}$ Smilax glabra rhizoma, extracting the sample with $5 \mathrm{~mL}$ of $60 \% \mathrm{MeOH}$ for ten minutes, centrifuging the solution, filtering the solution through a $0.45 \mu \mathrm{m}$ membrane, injecting $20 \mu \mathrm{L}$ of the extraction solution into HPLC-DAD system.

\subsection{Method validation}

\subsubsection{Specificity}

Simultaneous analysis of four samples including blank, standard, test sample, and standard addition test sample (spiked sample) obtained the results shown in Figure 2.

In the chromatogram of standard solution, AST's peak appeared at 19.9 min (Figure $2 \mathrm{~b}$ ), and it did not show in Figure 2a (blank sample). In the chromatograms of the test sample (Figure 2c) and the spiked sample (Figure 2d), there was a peak appeared at the same retention time $\left(t_{R}\right)$ of AST. The corresponding AST peak in the sample and the spiked sample was performed overlaid with the standard AST peak, giving a spectral superposition factor $>0.99$. The purity of the AST peaks in the sample and spiked sample also reached $>0.999$. Thus the method has sufficient specificity for AST.
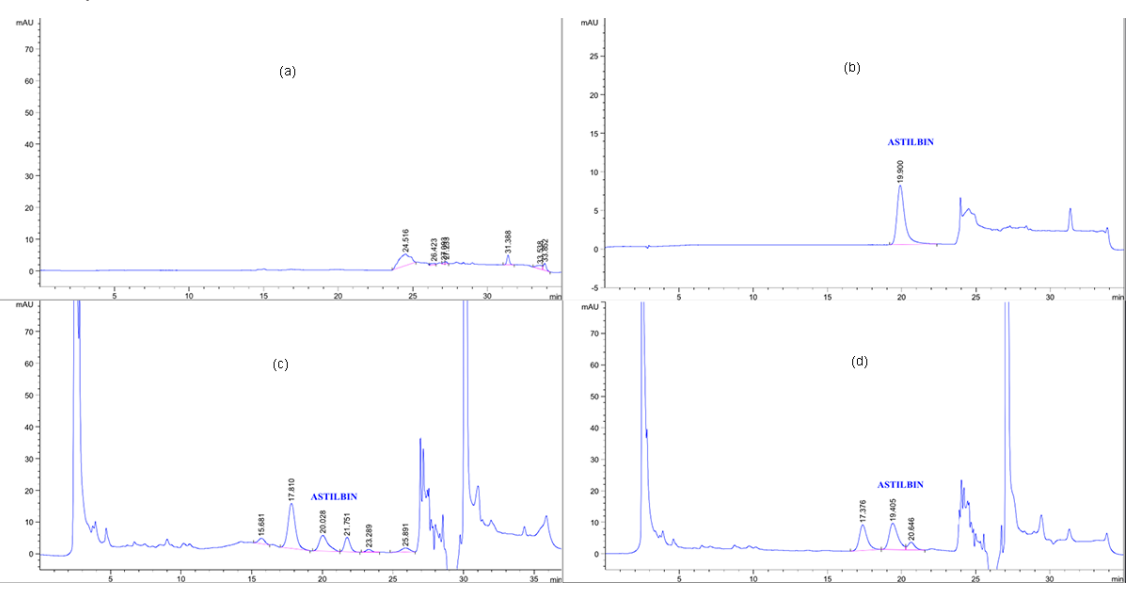

Figure 2. Chromatogram of blank (a), standard solution (b), test sample (c), and standard addition sample (d) 


\subsubsection{Systematic suitability}

Analysis of six replication of 10 ppm AST standard solution was recorded the retention time and peak area. The results showed that the relative standard deviation (RSD) of the retention time was $0.7 \%(<2 \%)$, of the peak area was $1.8 \%(<2 \%)$. These figures met the requirements of AOAC 2013.

\subsubsection{Calibration curve}

A series of AST standard solutions with actual concentrations of $1.077 \mathrm{ppm}, 2.152 \mathrm{ppm}$, $5.380 \mathrm{ppm}, 10.76 \mathrm{ppm} ; 16.14 \mathrm{ppm}$, and $21.52 \mathrm{ppm}$ were prepared, then analyzed with the selected conditions. The regression equation $(y=30.513 x-30.663)$ showed a good correlation between the peak area and the corresponding analyte concentration with the correlation coefficient $r=0.997$, which met the requirements of AOAC 2013.

\subsubsection{Repeatability}

T1 sample was weighed six times with a mass of about $0.125 \mathrm{~g}$. These samples were extracted ten minutes with $60 \% \mathrm{MeOH}$, then analyzed. We conducted this experiment twice with different analysts on different days to calculate the average. On the first day, the average amount of AST was $0.0353 \%$ w/w, RSD $1.50 \%$. On the second day, the average amount of AST was $0.0361 \% \mathrm{w} / \mathrm{w}$, RSD $1.37 \%$. The repeatability was acceptable with RSD for the amount of AST was $1.83 \%$, the average amount of AST was $0.0357 \% \mathrm{w} / \mathrm{w}$.

\subsubsection{Accuracy}

The accuracy of the method was determined by the following experiment: Adding an amount of AST standard to T1 sample such that the amount of AST in the extraction solution has a concentration range of 5 to $20 \mathrm{ppm}$; at each concentration, performing three replications. The concentration of AST in the samples was determined from the calibration curve. The results were presented in Table 1. The recovery was from 103.01\% - 106.45\%; RSD < 8\% meets AOAC 2013 regulations with a content of $0.01 \%(\mathrm{RSD}<6 \%$ at $0.1 \%, \mathrm{w} / \mathrm{w})$.

Table 1. Result of recovery experiments

\begin{tabular}{cccccc}
\hline Sample & $\begin{array}{c}\text { Addition concentra- } \\
\text { tion }(\mathbf{p p m})\end{array}$ & $\begin{array}{c}\text { Recoveryconcentration } \\
(\mathbf{p p m})\end{array}$ & $\begin{array}{c}\text { Recovery } \\
(\%)\end{array}$ & $\begin{array}{c}\text { Average } \\
(\%)\end{array}$ & RSD (\%) \\
\hline 1 & 2.152 & 2.229 & 103.61 & & \\
2 & 2.152 & 2.327 & 108.12 & 103.01 & 1.35 \\
3 & 2.152 & 2.094 & 97.29 & & \\
4 & 7.532 & 7.738 & 102.73 & & \\
5 & 7.532 & 8.075 & 107.21 & 106.45 & \\
6 & 7.532 & 8.241 & 109.41 & & \\
7 & 12.91 & 13.31 & 103.04 & & \\
8 & 12.91 & 13.73 & 106.33 & 105.80 & \\
9 & 12.91 & 13.95 & 108.04 & & \\
\hline
\end{tabular}




\subsubsection{Limit of detection (LOD) and limit of quantification (LOQ)}

AST standard solution was prepared at a concentration of $0.083 \mathrm{ppm}$. The ratio of AST's signal $\mathrm{S}$ and noise $\mathrm{N}(\mathrm{S} / \mathrm{N})$ was 3.5. Thus, $0.83 \mathrm{ppm}$ can be accepted as the LOD, and $0.25 \mathrm{ppm}$ can be the LOQ.

So far, the developed method was validated fully according to AOAC 2013, and suitable for determination of AST in SGR dietary supplements.

\subsection{Feasibility of the method}

To test the feasibility of the developed method, the above procedure was applied for the quantification of AST in several dietary supplements containing SGR on the market. The results were presented in Table 2. The results showed that the AST content has been determined in 2 samples of the SGR dietary supplements. In the remaining four samples, there was no peak corresponding to the retention time of AST. It meant that other ingredients in the products do not have peaks that affect the quantification of AST. This proved the feasibility of the method when applied to real samples.

Some products containing SGR did not show the peak of AST, although these products were assumed to have a high content in tablets. Due to the limited number of samples applied, it was not possible to comment on product quality, but this could be a suggestion to cooperate with manufacturers in testing input materials for production according to Vietnamese Pharmacopoeia V, and controlling the production process to avoid decomposition of active ingredients.

Table 2. Amount of AST in some SGR dietary supplements

\begin{tabular}{cccc}
\hline Sample & $\begin{array}{c}\text { Mass of a tablet } \\
(\mathbf{m g})\end{array}$ & $\begin{array}{c}\text { Concentration of AST in ex- } \\
\text { traction solution }(\boldsymbol{\mu g} / \mathbf{m L})\end{array}$ & $\begin{array}{c}\text { Amount of AST in a tablet } \\
(\mathbf{m g} / \text { tablet })\end{array}$ \\
\hline $\mathrm{T} 1$ & 100 & 4,639 & 0.1819 \\
$\mathrm{~T} 2$ & 100 & 4,212 & 0.1630 \\
$\mathrm{~T} 3$ & 330 & $\mathrm{ND}^{(*)}$ & $\mathrm{ND}^{(*)}$ \\
$\mathrm{T} 4$ & 650 & $\mathrm{ND}^{(*)}$ & $\mathrm{ND}^{(*)}$ \\
$\mathrm{T} 5$ & 100 & $\mathrm{ND}^{(*)}$ & $\mathrm{ND}^{(*)}$ \\
$\mathrm{T} 6$ & 100 & $\mathrm{ND}^{(*)}$ & $\mathrm{ND}^{(*)}$ \\
\hline
\end{tabular}

${ }^{(*)} \mathrm{ND}$ - Not detected $(<\mathrm{LOD} 0.08 \mu \mathrm{g} / \mathrm{mL}$ in extraction solution)

\section{CONCLUSION}

The study has developed a method for the quantification of astilbin in dietary supplements containing Smilax glabra rhizoma by high-performance liquid chromatography with a UV detector at $291 \mathrm{~nm}$ and simple mobile phases. The method of sample treatment by ultrasonic extraction with $60 \%$ methanol gives a high recovery, acceptable separation in the moderate analysis time, high sensitivity, repeatability, and accuracy meeting the AOAC guidelines [9]. The method has proven feasibility in determining AST content in commercial dietary supplements containing Smilax glabra rhizoma. 


\section{REFERENCES}

[1]. D. H. Bich, D. Q. Chung, B. X. Cương, N. Thuong Dong, D. T. Dam, P. V. Hien, V. N. Lo, P. D. Mai, P. K. Man, D. T. Nhu, N. Tap, and T. Toan, "Medicinal plants and animals in Vietnam," Hanoi: Science and Technology Publisher, vol.2, pp. 883-886, 2003.

[2]. L. Huang, J. Deng, G. Chen, M. Zhou, J. Liang, B. Yan, J. Shu, Y. Liang, and H. Huang, “The anti-hyperuricemic effect of four astilbin stereoisomers in Smilax glabra on hyperuricemic mice," Journal of Ethnopharmacology, vol. 238: 111777, 2019.

[3]. C-L. Lu, Y-F. Zhu, M-M. Hu, D-M. Wang, X-J Xu, C-J. Lu, and W. Zhu, "Optimization of astilbin extraction from the rhizome of Smilax glabra, and evaluation of its antiinflammatory effect and probable underlying mechanism in lipi-polysaccharide-induced RAW264.7 macrophages," Molecules, vol. 20, no. 1, pp. 625-644, 2015.

[4]. M. Huong, "Research on biological activities and chemical compositions in the roots of Smilax glabra rhizoma (SMILAX GLABRA ROXB.) in Vietnam," Master's Thesis in Experimental Biology, Institute of Ecology and Biological Resources, 2013.

[5]. P. T. H. Minh, N. Q. Tien, T. T. T. Hang, and P. H. Dien, "Research on the chemical composition of the Smilax glabra Roxb. grown in Thai Nguyen," Journal of Science, Hanoi National University of Education, vol 55, no. 6, pp. 62-70, 2010.

[6]. T. T. T. Van, V. V. Chien, P. T. Hang, P. V. Cuong, N. Q. Vuong, "Antioxidant activity of extracts and astilbin from the root of Smilax glabra of Vietnam," Malaysian Journal of Chemistry, 17, 12-19, 2015.

[7]. Pharmacopoeia Council - Ministry of Health, Vietnam Pharmacopoeia V, Medicine Publisher, vol. II, pp. 1344-1345, 2017.

[8]. L. V. Duc, V. B. Duong, T. N. Trung, and P. T. T. Huong, "Quantitative study for determination of astilbin in Smilax glabra by high performance liquid chromatography," Journal of Military Pharmaco-Medicine, vol. 7, pp. 8-12, 2015.

[9]. AOAC International, "Appendix K: Guidelines for dietary supplements and botanicals," AOAC Official Methods of Analysis, pp. 3-32, 2013.

[10]. Qing-Feng Zhang, Ying-Juan Fu, Zhan-Wang Huang, Xin-Cheng Shangguang, Yu-Xian Guo, "Aqueous Stability of Astilbin: Effects of pH, Temperature, and Solvent," Journal of Agricultural and Food Chemistry, 61 (49), 12085-12091, 2013. 


\title{
Xây dựng phương pháp địnhh lượng Astilbin trong thực phẩm bảo vệ sức khỏe có chứa thổ phục linh bằng sắc ký lỏng hiệu năng cao
}

\author{
Trần Nguyên Hà, Hoàng Thị Thuỳ Linh ${ }^{1}$, Vũ Ngân Bình \\ Nguyễn Thị Thanh Nhài ${ }^{2}$ Phí Văn Toàn ${ }^{3}$, Phạm Thị Thanh Hà̀ \\ ${ }^{1}$ Truởng Đại học Dược Hà Nội, Việt Nam \\ ${ }^{2}$ Truờng Cao đảng Dược Trung ương Hải Dương, Hải Dương, Việt Nam \\ ${ }^{3}$ Truờng Đại học Bách Khoa Hà Nội, Hà Nội, Việt Nam
}

\section{Tóm tắt}

Thổ phục linh (Smilax glabra Roxb.) là một dược liệu được sử dụng trong nhiêu bài thuốc cổ truyền về gân cốt, chống viêm, và gân đây cũng được sử dụng trong các thực phẩm bảo vệ sức khoẻ hỗ trợ điều trị viêm khớp và điều trị gout. Để kiểm soát chất lượng dược liệu Thổ phục linh, astilbin là hoạt chất được lựa chọn làm chất đánh dấu trong Dược điển Việt Nam V. Phương pháp định tính và định lượng astilibin trong sản phẩm bảo vệ sức khỏe chứa Thổ phục linh sắc ký lỏng hiệu năng cao (HPLC) đã được xây dựng trong nghiên cứu này. Astilbin trong chế phẩm được chiết siêu âm bằng methanol 60\%, phương pháp định lượng HPLC sử dụng cột $\mathrm{C} 18$, pha động gồm methanol và nước theo chế độ gradient, phát hiện bằng detector UV tại bước sóng $291 \mathrm{~nm}$. Các tiêu chí thẩm định phương pháp được thực hiện đây đủ theo hướng dẫn của AOAC 2013 cho kết quả tin cậy.

Từ khóa: astilbin, Smilax glabra, Thổ phục linh, thực phẩm bảo vệ sức khỏe, sắc kýlỏng hiệu năng cao, HPLC. 